\title{
Disaster Risk Management in the Province of Córdoba (Argentina): Participation Mechanisms in the Organizational Structure and Planning
}

\author{
Silvia E. Fontana \\ Universidad Católica de Córdoba \\ Argentina \\ Sofía Conrero \\ Universidad Católica de Córdoba \\ Argentina
}

Received: Jan. 28, 2019 Accepted: Feb. 15, 2019 Online published: Mar. 1, 2019

doi:10.5296/jpag.v9i1.14285 URL: https://doi.org/10.5296/jpag.v9i1.14285

\begin{abstract}
The most important mission of subnational governments in terms of disaster risk management is to plan and create structures and processes necessary for the construction of governance, stimulating communication among all the actors involved to strengthen the bonds of trust and the assumption of common responsibilities and individuals, and for a more efficient use of resources. On one hand, this raises important demands in terms of organizational redesign, counting on decision, communication and flexible relations processes that allow the articulation of people and resources within the organization and outside of it, in order to establish the different functions and results to be achieved through collaborative work, based on the objectives of disaster risk management. On the other hand, it requires a review of planning processes, with the participation of actors from all areas and levels, indispensable in the design and implementation, monitoring and evaluation of such planning. In this paper we analyze the ways in which the government of the province of Córdoba (Argentina) designs its organizational structure and raises its disaster risk management planning processes in a participatory manner, in order to guarantee joint work between government, civil society, private sector and at-risk populations.
\end{abstract}

Keywords: disaster risk management, planning, organizational design, participation, subnational government, province of Córdoba, Argentina 


\section{Introduction}

Disaster risk management must be thought like a process of articulation, planning and constant participation between the government and the different social actors, from both public and private sector. "Agreement, coordination, the possibility of achieving compatibility and intersectoral integration, in a consensual framework, is one of the keys of the implementation of a successful management. This is a complex task that involves the economic, political, social and cultural aspects of a society" (Herzer and others, 2002: 8).

During the last years in the territory of the province of Córdoba (Argentina) there have been countless disasters, from cases of floods, through droughts, severe storms and forest fires. These phenomena have caused serious consequences in terms of evacuated population, loss of agricultural productivity, damage to local and regional economies, among others.

Faced with this context, disaster risk management is an issue that is becoming important in the field of public policies and citizen practices. Thus, the theme is being added as a fundamental axis of sustainable development, taking into account for this the recommendations made by the United Nations Agency for Disaster Risk Management (UNISDR). Therefore, the province of Córdoba in 2015 decided to incorporate into its organizational structure a specific area that would carry forward everything related to disaster risk management, creating the Secretariat of Climate Risk Management and Catastrophes with the idea of improving public safety through the efficiency of risk management throughout the Province.

However, it is necessary to recognize the complexity of disaster risk management. That is to say that the application of this approach is not limited to the creation of an area within the government's structure. It has to be conceived as a transversal policy that promotes development, and in order to do that a more cooperative form of government in which diverse actors participate in the design and implementation of policies is required. In this model, the participation and interaction of the actors become relevant in an environment of action that is dynamic.

The fundamental mission of subnational governments in terms of disaster risk management is to plan and create structures and processes necessary for the construction of governance, stimulating communication among all the actors involved to strengthen the bonds of trust and the assumption of common responsibilities and individuals, and to guarantee a more efficient use of resources.

We start by considering governance as a new interdependent way of governing. This means that the definition of policies is no longer carried out exclusively by the government, but that private and social organizations also should participate in this process. The government becomes a node of a network in which it is jointly deliberated, interacted, co-produced with other actors in society (Aguilar, 2014).

In this article we propose to analyze the ways in which the government of the province of Córdoba (Argentina) designs its organizational structure and raises its disaster risk management planning processes in a participatory manner in order to guarantee joint work 
between government, civil society, private sector and at-risk populations. To this end, a documentary survey and in-depth interviews have been carried out with various actors involved in disaster risk management.

\section{Risk Management and the Search for Integrality Through Participation}

\subsection{An Approach to Disaster Risk Management}

It is possible to ask: can something be done in the face of disaster risk? or is it like trying to handle the unknown and / or uncertain? (Fontana, 2016).

Since the emergence of the disaster risk management approach, it has been evolving almost permanently. We can highlight at least three major moments that led to the construction and development of this approach.

1. First moment (until the 70's): disasters were considered from the natural phenomenon that had already occurred, so that it could only be answered through concrete response and assistance actions. At this stage, disasters were understood as difficult phenomena to avoid, and the assistance provided was typical of civil defense institutions and voluntary organizations. This stage is encompassed by an emergencist approach.

2. Second moment (from the 1970s): the need arises to begin to carry out disaster prevention as well as to try to take actions to reduce those phenomena that cause disasters. It is international organizations that lead and invite governments to manage disasters in this line of preventive action. Among the main organizations that promote prevention are the United Nations (UN), the Organization of American States (OAS), the Pan American Health Organization (PAHO), among others.

3. Third moment (from the 1990s): the United Nations (UN) declared the decade of the '90s as the International Decade for the Reduction of Natural Disasters, through the Resolution 42/169 of the General Assembly, so that the risk reduction was installed in the speeches and actions sustained particularly by a group of International Organizations ${ }^{1}$.

The reduction of disaster risks is defined as the "execution of intervention measures aimed at reducing or diminishing the existing risk" (Lavell, 2003: 69). That is why disaster risk reduction is a significant and unavoidable component for development, since development would be unsustainable if there were progressive increases in the levels of risk that society should bear, leading to higher levels of damages and losses for the population (Lavell, 2002b).

Therefore, risk reduction is considered as a complex social process and not merely as a product obtained from the implementation of several actions tending to reduce the negative effects of a possible disaster. The reduction of disaster risk was the first approach in the

\footnotetext{
${ }^{1}$ There are several international organizations that have spaces devoted to the topic of disaster risk in their structures. Examples are the Inter-American Development Bank (IDB), the World Bank (WB), the United Nations Development Program (UNDP), the Pan American Health Organization (PAHO), UNESCO, UNISDR, ECLAC, the of American States (OAS), among others.
} 
search for a paradigm that exceeded the simple response, recognizing the existence of risk.

The notion of Disaster Risk Management ${ }^{2}$ is already well underway in the 1990s. Alan Lavell defines disaster risk management as a "complex social process that leads to the planning and application of policies, strategies, instruments and measures aimed at preventing, reducing, anticipating and controlling the adverse effects of dangerous phenomena on the population, goods and services and the environment. Integrated actions to reduce risks through prevention, mitigation, preparation for and response to emergencies and post-impact recovery" (2002a: 19).

For its part, the International Strategy for Disaster Reduction (ISDR) defines risk management as "the systematic management of administrative decisions, organization, technical capacity and responsibilities for the implementation of policies, strategies and actions for the reduction of disaster risks" (ONU-CEPAL, 2005: 27).

From both definitions we see that disaster risk management cannot be seen as an isolated practice or action, so "it should be considered as an integral and functional component of development management, be it national, sectoral, territorial, strategic, urban, local or community, and environmental management, in search of sustainability" (Metropolitan Caracas Strategic Plan Association 2002 - 2003).

This process involving disaster risk management involves certain challenges:

* It must be apprehended by all sectors of society, and not be an instance of the government level, who must promote its momentum, practice and application.

* It constitutes an integrating axis that crosses horizontally all phases of the disaster cycle, that is, from the risk prevention stage to the disaster reconstruction stage (Cardona, 1996; Flores, 2006; Lavell, 2002b; Ramos Álvarez, 2004).

The purpose of the disaster risk management approach is to "ensure that the development processes promoted in society take place under the optimal conditions of possible security and that the attention given to the problem of disasters and the action taken to face them and their consequences promote up to the maximum the same development" (Caracas Metropolitan Strategic Plan Association 2002 - 2003).

Thus, from the 1960s onwards, a series of disasters that globally impacted society began to take place. This reality led to a profound rethinking about the emergencist or simple response that one had about disasters. Therefore, and as stated above, the United Nations through General Assembly Resolution 42/169 raised the need for governments to implement policies aimed at preventing and mitigating risks in the face of natural hazards, adding the reduction of disaster risks in the agendas of governments and development.

From this approach and around disaster risk management, various ways have been highlighted through which governments, at their various levels, can incorporate the topic of

\footnotetext{
2 The use of this concept is attributed to the Social Studies Network in Disaster Prevention in Latin America (LA RED).
} 
risk into their agendas.

The United Nations Development Program (UNDP) argues that there are three ways to manage disaster risk by governments (Lavell, 2003):

* Corrective or compensatory management: promotes the implementation of measures and actions previously with the aim of promoting the reduction of vulnerability. This way of managing is executed based on the results obtained through risk analysis carried out, as well as considering the historical memory of disasters. Through this perspective, we seek to reverse those causes that originate the risks.

* Prospective management: this type of management seeks to adopt measures and actions in development planning that lead to avoid the appearance of new vulnerabilities or deepen existing threats, as well as reduce existing ones. Prospective management involves the analysis of future risk in order to determine the level of acceptable risk.

* Preparedness for the response to the emergency: includes being constantly alerted and prepared for the possible occurrence of any eventuality, in such a way that the costs associated with emergencies are of less impact.

Based on this typology, the United Nations System promotes prospective risk management since it deals with the causes of disasters and is the most efficient way to reduce the damage that could be generated once the threat is unleashed.

Ana Flores (2006) from her position suggests that risk management is understood as a government process and responds basically to two models:

* Integral Models: this model aims to integrate risk management in all areas (institutions, organizations, companies, etc.) and sectors (public and private) of society. In this context, the actions start from a risk management policy, and from the organizational structure that incorporates criteria for the prevention or anticipation of risks and disasters, then the operations that take place in emergency situations or disasters, and culminates with the actions of repair, rehabilitation or reconstruction of the areas affected by disaster situations. This model is always applied by those governments that have considered the importance of prevention as a sustainable development strategy, and the political willingness will generate the necessary conditions for its strengthening and constant improvement.

* Reactive Models: is the kind of model in which the actions of governments, the public sector, the private sector, and communities in general are mobilized only when emergency scenarios and / or disasters occur.

It is important to emphasize that risk management places decision-makers in front of the actions that must be put into play in the event of a disaster occurring or possible, that is, in the face of the uncertainty that an event may or may not happen. If we consider that the elements that contribute to the occurrence of a disaster are heterogeneous, their analysis cannot be reduced to only one aspect, which is why disaster risk management is now addressed from a more integral perspective. Against this we argue that "disasters are the result of a broad spectrum of threat agents operating in any given environment; they vary 
from natural to man-made and can impact the affected populations in different ways" (Mocellin and Rogge, 1996: 178).

Hilda Herzer argues that "risk management involves not only government intervention but also the interaction of different public and private social actors that incorporate risk hypotheses in their interaction with society" (Herzer and others, 2002: 5).

This type of events, caused by nature and by human actions and / or omissions, can show the ability of governments to respond to situations that emerge or, they can also highlight the vulnerability of institutions that show their inability to give an answer to the risk already materialized.

There are lots of diverse measures and actions that can be implemented by governments to manage disaster risk, among which we can mention: preparation of adequate legislation, allocations in the budget and decentralization of responsibilities in order to achieve the participation of subnational governments; local governments and civil society in the decision-making process. Flores argues that, "the institutionalization of Risk Management is necessary in this process of incorporating conscience, capacity and transforming will into the activity of the State and that of all social actors" (2006: 11).

\subsection{Integrality in Disaster Risk Management}

Faced with this, it is advisable to implement a comprehensive approach to risk ranging from the prevention of risks to the subsequent recovery in the event that the disaster has materialized, as well as being comprehensive in its planning process. This approach includes a number of actions "that articulate the institutions with the political practices and with the technical procedures of analysis and management" (Aguilar Villanueva, 2006: 92):

* Risk analysis in order to determine the class and severity of the same for the population as well as the investments that must be made.

* Prevention and mitigation measures to address the structural causes of vulnerability.

* Transfer of risks with the objective of distributing the financial risks over time and among the protagonists.

* Preparedness and intervention in emergency situations so that countries are prepared to deal quickly and effectively with emergency situations.

* Rehabilitation and reconstruction after disasters to provide an effective recovery and create guarantees against future disasters (Flores, 2006).

One important reason for the incorporation of disaster risk management into the agendas of governments is that when a disaster occurs, all the public patrimony of society is affected. Thus, public management becomes significant and non-delegable for disaster risk reduction (Gurevich, 1997).

Likewise, disaster risk reduction benefits development, since development without risk management is nothing more than an empty word (Lavell, 2002b, Herzer and others, 2002). 
This assertion emphasizes the importance of disaster risk management in the framework of sustainable development, understanding that incorporating risk management is a responsibility of governments and civil society, and remembering that people are the center of development. Incorporating disaster risk management into development planning corresponds to considering the dimensions that will give sustainability in the long term to that process.

At the beginning of the 21st century, the General Assembly of the United Nations raised the Millennium Development Goals ${ }^{3}$, considered the "new commitments acquired by the international community in the fight against poverty that offer a new framework of action for disaster prevention and risk reduction" (Rodríguez Velázquez, 2008: 63).

Faced with these objectives proposed by the United Nations, the reduction of disaster risk became one of the great challenges for development, so that achieving the reduction of vulnerabilities and exposure to risk, as well as increasing the capacity of response, require an integral approach to disaster risk.

It is worth noting that the participation of local, regional and national governments, international organizations, private actors and civil society must be included in disaster risk management policies, from the moment of analysis to the moment of the assessment of disaster risks. In this sense, it is argued that "risk management will then be and only viable if technical - scientific work, political - administrative will and community participation converge, so that its effectiveness and sustainability will be achieved only if it is based on:

(a) Decentralization and strengthening at the local level;

(b) The participation of the private productive sector and civil society organizations;

(c) Transparency in the handling of information; and

(d) The audit of the results "(Solanas and others, 2011:15).

This inter-institutional disaster risk governance must be decentralized, participatory and politically backed, in order to strengthen the efforts that are made in disaster risk reduction, and that sometimes appear to be inefficient due to the lack of coordination between different sectors.

Thus, integrated disaster risk management will only be viable if it flows from the coordinated work of all the actors involved in the process, so that in order to be efficient and sustainable they must be instituted based on:

* The strengthening of the local level of government, since it is territorially who is closest to

3 The Millennium Development Goals are an agreed plan within the framework of the UN with the objective of improving the future of the peoples. Part of a reflection made in the General Assembly in which the future of human generations was put into debate. To this end, eight specific objectives were set: eradicate extreme poverty and hunger, promote global partnership, combat HIV / AIDS, improve maternal health, reduce child mortality, promote universal education, promote equality between the genres and guarantee the sustainability of the environment (Vía Internet http://www.un.org/es/millenniumgoals/bkgd.shtml). 
the problem;

* The participation of the public and private sectors that are part of society, since joint and coordinated work is necessary;

* The transparency of the information that allows the knowledge of the data to work accordingly; and

* The evaluation of the processes that are carried out, for the improvement of the actions implemented.

Precisely achieving an articulation in risk management is an indispensable factor due to the need to strengthen a new way of interconnecting governments, civil society and the private sector.

\section{Governance of Disaster Risk: Participation Mechanisms}

\subsection{Through Organizational Design}

In organizational design, one of the elements to be considered when analyzing the mechanisms of participation in disaster risk management is the design of its structure, which is why it is important to point out the need for government organizational structures to have the capacity to promote and coordinate both prevention and disaster response, enabling collective action of all society (Vargas, 2002). This requires strengthening the organizational and administrative risk management systems, adapting them to the reality of possible disasters, which implies decentralization processes in the responsible public administrations and the incorporation and participation of civil society, among other elements (Clarke and Pineda Mannheim, 2007).

The structure of an organization is the set of all the ways in which work is divided into different tasks, being its key coordination to achieve the common objectives of the organization (Mintzberg, 1998). The structure formally represents relationships, communications, decision processes and procedures that articulate people, material resources and functions around objectives and results (Ramió, 1999). The design of organizational structures is not only a technical issue, but is, fundamentally, a political decision (Peters, 1999). Different organizational designs can facilitate or hinder the access of different actors, issues, priorities and resources, influencing the behaviour of organizations and the development of policies (Laegreid and Verhoest, 2010).

In this sense, a key tension occurs between what implies the participatory approach of disaster risk management and the design of structures, even with high levels of bureaucratization, especially in public administrations (Fontana and Conrero, 2017). The needs of horizontalization, flexibility and redefinition of functions are key for the articulation of networks (Agranoff, 2012), a central requirement in this topic.

For the analysis of the organizational structure, several components can be considered. Among them, the formalization of jobs, horizontal and vertical specialization, and coordination mechanisms are key components to facilitate or hinder a participatory approach 
in disaster risk management.

The creation of new areas in public organizations, with jobs linked to achieving specific objectives and specific tasks, shows that a certain issue has entered the government's agenda. Likewise, if we add to this analysis the presence or not of one of the classifications of the organizational structures, the organization by purpose, it can be understood if the theme or policy that is to be developed is part of the organizational purposes or goals (Peters, 1999).

Regarding specialization, the hierarchy or vertical specialization accounts for the differentiation of responsibility in the different hierarchical levels, as well as refers to the communication mechanisms between the units of the organization and the speed in the decision-making processes (Ramió, 1999; Laegreid and Verhoest, 2010). The participatory approach to disaster risk management requires fluency and multidirectionality in communication, as well as the incorporation of multiple and diverse actors in the decision-making processes, and this must be reflected in the design of the organizational structure.

For its part, horizontal specialization refers to the specialization of work that configures different areas of management, in each of the hierarchical levels. This allows the grouping of jobs whose activities are articulated for a more effective and efficient achievement of the objectives (Ramió, 1999).

The specification of authority relationships between units to increase control over the behaviour of the entire organization (command and control principle) raises a deterministic model that seeks to reduce uncertainty. This model works well in conditions of stability, but it presents difficulties to respond in dynamic and uncertain conditions, since they tend to close under complex and changing conditions, such as those currently facing disaster risk (Clarke and Pineda Mannheim, 2007).

Both vertical and horizontal specialization require coordination mechanisms to align the tasks and efforts of each organizational unit to achieve a common goal (Laegreid and Verhoest, 2010). In contexts of greater participation of actors, as the management of disaster risk, it is fundamental that these mechanisms are defined and agreed among all the participants, in such a way that the integral approach of the subject is not lost.

The new organizational designs raise the need to establish institutional networks of public, private and civil society entities, coordinated at the national level and with replicas at the provincial and municipal level that promote disaster risk management, aimed at preventing or reducing the loss of lives, damage to property and the environment, decreasing the social and economic impact (Clarke and Pineda Mannheim, 2007). The clear definition of roles, functions and responsibilities of each entity, as well as coordination mechanisms, are fundamental in an inter-institutional system of these characteristics.

\subsection{Through the Planning Processes}

In disaster risk management it is necessary to be prepared to face a threat, which implies the involvement of technical, social and political elements (Herzer, 1990). The latter refer to the 
necessary agreements between public institutions, organizations and the population. Based on the elements mentioned above, Herzer defines planning as a dynamic and continuous process over time that involves the collection of information and the generation of interpersonal and interorganizational agreements and relationships, which are subject to constant changes (Herzer, 1990).

In concordance with what was proposed by Herzer (1990) is the theoretical approach that conceives planning as a social process. From this perspective, the need to overcome the purely technical conception of planning is understood, in order to understand it as a process in which "various functional demands and different coalitions of actors interact systematically" (Herrera Gómez and Requena, 2002: 61).

Planning is ultimately the structured interaction between actors, who not only play differentiated roles but also control different types of resources and have different expectations. These differences between them mean that the planning process is characterized by the search for compatibilities, through the continuous negotiation between them, in an environment that is, at the same time, dynamic. According to the above, it can be inferred that, under this logic, even the identity of the planner is transformed, and this must complement his technical competence with his communicative and negotiating skills (Herrera Gómez and Requena, 2002).

As it was already pointed out, for Herzer (1990) planning the emergency means being ready to respond to risks, i.e. being ready to act in the face of a threat, identifying it, monitoring it and mobilizing the necessary resources to reduce its impact; implying all this a dynamic and semi-structured process. This is highly related to the concept of social construction of risk, since risk is built on the interaction between society and the environment.

Given this, it is important that the planning be dynamic and semi-structured, so that it allows a certain flexibility and adaptability to changes (of the environment, agreements and relationships). For Herzer (1990) planning must include all stages of risk management: prevention and mitigation (before), response (during) and recovery (after) and supposes the articulation between sectors, organizations, institutions and the population, in order to meet the objective pursued: minimize the damage and material and human losses.

In line with these theoretical approaches is the approach called participatory planning and associated management, which is basically a modality for decision making in the field of public policy. According to Poggiese (1993), participatory planning and associated management is a dynamic process of constant transformation that seeks to overcome the limits of traditional planning and the production of knowledge-action, based on a democratic expansion of decision-making and social participation.

The central core of this approach is social participation, with an essential assumption that raises the possibility of co-management, i.e. the distribution of responsibilities between State and society and the possibility of mutual influence between them. Like the planning approach as a social process, from the approach of participatory planning and associated management, it is sought to overcome not only the obstacle of sectoriality but also, and above all, the 
technocratic dominance generally prevailing in the decisional areas, advocating, on the other hand, for a joint construction of public policy decisions.

In summary, the approach of participatory planning and associated management conceives the planning process as dynamic, democratizing that seeks to expand decision-making and social participation. This is a key element because risk management attempts to provide society with the capacity to reduce vulnerabilities, and the tool of participation in this process is essential.

\section{The Córdoba Case: The Mechanisms of Participation in the Planning Processes and in the Organizational Design}

The province of Córdoba is located in the center of the Argentine Republic, and is crossed by five river basins, three mountain ranges and most of its territory is dedicated to agriculture and livestock. This provincial territory presents environments of great variety in terms of geography, highlighting various strengths and vulnerabilities of the territory that acquire particular relevance when considering the possibility of a disaster.

It is noteworthy that the relief of the province of Córdoba is a determining factor in its geography. Especially, the hydrographic network of the Province is constituted by five rivers that are characterized by having an irregular regime that reaches significant flows during the summer.

Floods, heavy storms, forest fires, droughts and desertification have caused countless disaster scenarios over the last years in the province of Córdoba. These phenomena have made visible various vulnerabilities on the part of society and local governments in risk management, prevention policies, disaster mitigation, emergency management and in the reconstruction phase.

\subsection{The Secretariat of Climate Risk Management and Catastrophes: Organizational Structure and Planning}

The Secretariat of Climate Risk Management and Catastrophes was created in December 2015 , right after the inauguration of the new governor of the province of Cordoba, and located under the orbit of the Ministry of Government. Among the foundations of its creation it is stated that it aims to improve public safety through the efficiency of risk management throughout the province of Córdoba.

The creation of this area in the organic design of the government of the province of Córdoba is the concrete and visible expression of the entrance of the issue of risk management to the provincial government's agenda. Although previously there were already some areas that incorporated the disaster risk management approach into their functions, such as Civil Defense and the Provincial Fire Management Plan, the formalization of an area with a specific denomination points out that the subject enters to the management of government.

Specifically, and according to the organizational structure, the official in charge of the Secretariat of Climate Risk Management and Catastrophes is granted the following competence: 
* Collaborate in the creation of a ministerial portfolio to improve public safety through the efficiency of risk management and intervention in the emergency in the province of Córdoba.

Likewise, a series of functions are established, among which the following are particularly mentioned for the management of climatic risks and catastrophes ${ }^{4}$ :

* Assist the Ministry of Government in everything inherent to the policies of planning and coordination of civil defense, Nautical Safety, the application of Law $\mathrm{N}^{\circ} 8.751$, Fire Management, and the design and management of programs of dissemination, training, prevention and response in situations of provincial emergency in the presence of natural and / or anthropogenic adverse events and forest and rural fires.

* Implement the Provincial Emergency Board, coordinating with: Municipalities and Municipalities, Cordoba Police, General Directorate of Aeronautics, Health Emergencies Directorate, Social Emergencies Directorate, Environmental Emergencies Directorate, Fire Management Plan Directorate, Communications Network of Provincial emergencies, the volunteer firefighters system, and other public and / or private institutions that are of interest or when requested, respecting the application of the (SCI) according to the typology of the event in question.

* Allocate resources in accordance with Law $\mathrm{N}^{\circ} 8.751$ and amending the Provincial Fire Management Fund.

* Develop, coordinate and evaluate the actions and programs financed with resources in accordance with Law $\mathrm{N}^{\circ} 8.751$ and amending the Provincial Fire Management Fund.

* To attend and evaluate any request for economic assistance made in compliance with the object and purposes of Law 8.751, bearing in mind the Annual Plan for the Prevention and Fight against Fire in Rural Areas and / or Forest, the Map of Fire Risk Zoning, the Need and Urgency of the case and the statistical reports surveyed.

* Operate the Single Emergency Communications Network of the Province.

* Represent the Ministry of Security before the Federal Council for Civil Protection and Risk Management.

* Monitoring of the administrative control of the Volunteer Firefighter System of the Province in accordance with Law No. 8,058 and its Regulatory Decrees.

* Ensure the application of Law No. 9,089 (Volunteering).

* Follow-up of survey actions and inventory of equipment, uniforms or materials of the Volunteer Firemen Associations.

* Indicate to the Civil Defense the audit and control of the operative capacity of the Voluntary Firemen Institutions that participate in the forest and / or rural fires.

\footnotetext{
${ }^{4}$ http://www.cba.gov.ar/reparticion/ministerio-de-gobierno/secretaria-de-gestion-de-riesgo-cli matico-y-catastrofes/
} 
In the first place, to analyze its functions and understand the interaction with the other entities dependent on it, the design of the Secretariat is characterized by establishing a hierarchical structure that allows it to develop its functions and in turn delegate competencies. Among the functions that the Secretariat has, are those of "assisting the Ministry of Government in everything inherent to planning policies" and that of coordinating the three directorates that comprise it: Directorate of Civil Defense, Directorate of the Provincial Management Plan of the Fire and Nautical Security Directorate. Of these three directorates, the first two are those that have competence in the work of disaster risk management itself.

In turn, another of the primary functions of the Secretariat is to promote "the design and management of dissemination, training, prevention and response programs in provincial emergency situations in the presence of adverse natural and / or anthropic events and forest and rural fires". This function is closely linked to centralization and decentralization in decision making. This tension centralization - decentralization goes through all levels of the organizational structure of the Secretariat, especially given the subsidiary nature of civil defense in Argentina.

The centralization in decision making is presented, very particularly, in cases when the emergency exceeds the possibility of local authorities and / or actors territorially located or close to the place to resolve it. This can happen due to: 1) the magnitude of the emergency, 2) the lack of resources (material and economic) to be able to resolve it having to resort to the Secretariat and its respective dependencies and, 3) the lack of planning of the Municipalities in relationship with the emergency, for which they are also forced to obtain help from the Secretariat.

In particular, the Directorate of Civil Defense of the province of Córdoba, in the exercise of its functions, has as its main competence "centralize and direct the tasks of distribution of the means of aid to the victims" 5 , so it is possible to underline the importance that has the centralization in the decision making at the moment of providing immediate solutions in front of the emergency.

It should be noted the growing commitment of the Directorate of Civil Defense in coordination with the Secretariat of Climate Risk Management and Catastrophes in encouraging municipalities to conform their area of disaster risk management in their respective jurisdictions and thus achieve, within the competences of said organization, a greater participation in risk reduction. The objectives of this proposal are multiple, but among the most important is to achieve decentralization in decision-making in order to be able to act more effectively in situations that directly affect the municipal jurisdiction in question.

It is interesting to note that, although incorporation into the organization chart of the Secretariat of Climate Risk Management and Catastrophes is proposed from a bureaucratic design in terms of vertical and horizontal specialization, in the design of its functions, and in its addresses in charge, the incorporation of articulation with diverse actors is observed both for the design of the policies in this subject, as well as in its implementation.

${ }^{5}$ http://www.cba.gov.ar/direccion-de-defensa-civil/ 
On the other hand, special attention should be given to the coordination mechanisms and the interdependence scenarios between different levels and areas of government, and other actors necessary to achieve the objectives of the Secretariat of Climate Risk Management and Catastrophes of the province of Córdoba.

The government of the Province of Córdoba, from the creation of this Secretariat, has as its goal to achieve an agile, decentralized and coherent organizational structure that systematically integrates the action of public and private entities. Particularly, it shows its interest in it since it was one of the first Argentine provinces that adhered to the National Comprehensive Risk Management and Civil Protection System (SINAGIR).

In June 2017, the province of Córdoba adhered to the National Law $\mathrm{N}^{\circ} 27.287$, through which the National System for Comprehensive Risk Management and Civil Protection (SINAGIR) is created. Although it is worth clarifying that it is not yet regulated, it is expected that its actions will be visible, mainly, in the articulation of the actions of the different levels of government, non-governmental organizations and civil society, integrating them and giving them a greater participation and involvement to be able to manage the risks. In turn, this law creates two funds: one destined for emergency and the other for prevention.

Another example is found in the functions developed by the Secretariat and refers to the implementation of the "Provincial Emergency Board" by which it seeks to carry out a dialogue table between the different institutions that are directly affected by the emergency. It is important to emphasize that these do not have a purely public nature, but also private actors are included, such as different churches, neighborhood clubs, NGOs and universities, depending on the type of event in question. Therefore, it is observed that there is a slow but growing tendency on the part of the Secretariat to be an articulating space for actors of different nature, as well as generating spaces and mechanisms for the participation of "new voices" in disaster risk management.

While it is true that specifically the "Provincial Emergency Board" is an instance of reactive response to the emergency, that is, it acts on present needs when a catastrophe occurs and not on the mitigation and prevention of it, the Secretariat of Management of Risk, insists on the importance of participation to manage disaster risk. Since its creation, the Secretariat has tried and partially managed to take on a more active role in interacting with different actors.

It is also important to note that the Secretariat, through the Directorate of the Provincial Fire Management Plan, carries out various activities in this area. One of them is the training program aimed at local government personnel as a strengthening mechanism for the reduction of the risk of forest fires, as well as for the increase of response capacities in front of this type of events.

In this area, centralization appears strongly linked to the competence of "allocation of resources according to Law $N^{\circ} 8751$ and amending the Provincial Fire Management Fund". In this sense, the Secretariat makes a permanent effort to articulate resources and set priorities before the different emergencies in front of forest fires, as well as in the determination and in the establishment of priorities in the assigned resources to neutralize the different fire sources 
that can arrive to occur in the province of Córdoba.

The risk management in the government of the province of Córdoba is not limited to the scope of the dependent Departments of the Secretariat of Climate Risk Management and Catastrophes. For example, in hydrographic matters, the planning of disaster risk management, particularly of river basins, is coordinated through the Multisectoral Committee for Integrated Management of Basins of Córdoba, created in January 2016 ${ }^{6}$. It is integrated by diverse actors that establish the planning in the basins, they are:

- The Ministry of Agriculture and Livestock, the Ministry of Water, Environment and Public Services, the Secretariat of Environment and the Secretary of Water Resources,

- The Canaleros Consortia and the Camineros Consortia,

- Table Negotiations between the Province and Municipalities;

- Legislators of the ruling and opposition blocs,

- Basin Committees of each of the basins.

This Multisectorial Committee also has the assistance of external advisors for consultations when the situation requires it, such as the National Water Institute (INA), the National University of Córdoba (UNC), the Inter-Cooperative Confederation of Agricultural Limited (CONINAGRO), the School of Agricultural Engineers of the province of Córdoba, in the National Institute of Agricultural Technology (INTA) and the Planning Institute of the Province of Córdoba (IPLAN). The Multisectorial Committee arises from the need to interdisciplinary approach and develop articulated policies around a management unit that is the water basin, taking the idea of watershed management as an integrated system ${ }^{7}$.

In its beginnings the Multisectorial Committee defined the priorities and established its future actions that are based on:

* Carrying out an evaluation of each of the basins and reviewing their problems,

* The analysis of the status of the executed works, their operation,

* The improvement of existing infrastructure, and

* Complementation with a work if necessary.

* The need to coordinate activities with existing Córdoba consortiums and those that may subsequently be formed,

* The prioritization of actions in terms of rural and urban connectivity to get production out of the province,

\footnotetext{
${ }^{6}$ http://prensa.cba.gov.ar/politica/se-conformo-el-comite-multisectorial-de-gestion-integradade-cuencas-de-cordoba/
}

http://prensa.cba.gov.ar/politica/se-conformo-el-comite-multisectorial-de-gestion-integrada-d e-cuencas-de-cordoba/ 
* The assurance of the good condition of the roads so that the floods do not represent productive problems, all this under the integral view of the natural resources and their conservation ${ }^{8}$.

Until these days the Multisectorial Committee of Integrated Management of Basins of Córdoba have worked without a regulation or statute that regulates it. Despite this, decisions are made jointly by all members. Each member of the Committee actively participates and contributes from their area of expertise to have a more complete and holistic view of the problem to be addressed, meaning that participation is always open ${ }^{9}$.

This type of organizational design facilitates that the solutions are built collectively and planned on the moment according to the problems that arise. Internally the Committee works in an articulated manner among its actors through meetings and the elaboration of projects that require the contribution of each area, but each one maintains the autonomy to follow its established operation, since it is mainly worked according to the problem and starting from that, guidelines are generated to address it.

It is necessary to emphasize that defining operational procedures that facilitate the action of the entities involved in accordance with the scope of their competence, and establishing mechanisms for inter-institutional coordination and civil society for the management of all phases of disaster risk requires a large coordination, to avoid duplication of functions and reduce the time elapsed between the formulation of projects, their study and approval, and finally their implementation for rehabilitation and reconstruction.

\section{Conclusions}

The government of the province of Córdoba has added the subject of disaster risk management into its government agenda, which constitutes a positive step forward to address the challenges posed in the international framework documents on the subject (Hyogo Framework for Action, Sendai Framework, etc.).

A clear policy regarding this is the creation of the Secretariat of Climate Risk Management and Catastrophes. The existence of the area in the organizational structure accounts for the entry of the issue into the government's agenda, although it is too early to say that its actions are truly thought from the perspective of disaster risk management. It was incorporated into the organizational chart as an area within a rigid bureaucratic paradigm, although with some flexible components that contemplate participatory processes in planning and decision making.

The functions of the Secretariat and its activities are located around an unsolved tension between centralization and decentralization, especially in relation to local governments. On one hand, the development of capacities at the local level is trained and encouraged, but in some aspects, such as resource management and emergency response, centrality is used in the decision-making process from the Secretariat.

\footnotetext{
${ }^{8}$ https://www.youtube.com/watch?v=7uoutSRWTtk

${ }^{9}$ Interview with a member of the Legislative Power of Córdoba.
} 


\section{Macrothink}

Journal of Public Administration and Governance

ISSN 2161-7104

2019, Vol. 9, No. 1

There is a broad definition of functions, but they lose specificity in the approach to disaster risk management. Although, this low specificity can be seen as a benefit in terms of flexibility, an aspect required by the new organizational designs, it also makes it difficult to coordinate and interrelate with all the actors involved in terms of responsibilities and execution of activities.

The Provincial Plan for Fire Management and the Multisectorial Committee for the Integrated Management of Basins of Córdoba are the outstanding cases in the development of participation and coordination mechanisms for disaster risk management. Although there is still a reactive manner, with little planning, these actions incorporate the participation of extra governmental actors.

It is important to emphasize that the policies of disaster risk management are long-term, so that their sustainability over time depends directly on agreements between all the actors involved. And this is still the main challenge in which the government of the province of Córdoba should continue working in order to improve its development.

\section{References}

Agranoff, R. (2012). Collaborating to Manage: A Primer for the Public Sector. Washington DC: Georgetown University Press.

Aguilar, V. L. F. (2006). Gobernanza y Gestión Pública. México: Fondo de Cultura Económica.

Aguilar, V. L. F. (2014). Las dimensiones y los niveles de gobernanza. Cuadernos de Gobierno y Administración Pública, 1, 11-36.

Asociación Plan Estratégico Caracas Metropolitana. (2002 - 2003). Visión 2010. Boletín Electrónico, 25(5).

Cardona, O. D. (1996). El manejo de riesgos y los preparativos para desastres: compromiso institucional para mejorar la calidad de vida. Mansilla, Elizabeth (edit.), Desastres. Modelo para armar. Colección de piezas de un rompecabezas social. La Red. [Online] Available: www.desenredando.org. (January 28, 2019).

Clarke, C., \& Pineda, M. C. (eds.) (2007). Riesgo y desastres: su gestión municipal en Centroamérica. New York: Interamerican Development Bank.

Flores, A. R. (coord.) (2006). Actores y Roles en la Gestión del Riesgo. Asunción: CYTED.

Fontana, S. (2016). Se puede hacer algo frente al riesgo de desastres? ¿Comunicar el riesgo o el riesgo de comunicar. Revista Más Poder Local, 29, 8-10.

Fontana, S., \& Conrero, S. (2017). Estrategias de gobierno para gestionar el riesgo de desastres: planificación, diseño organizacional y comunicación. Revista Estado Abierto, 2(1), 183-202.

Gurevich, R. (1997). Ciudad y desastre: un reto para la gestión pública. Herzer, H. (comp), Postales urbanas del fin del milenio. Una construcción de muchos, Buenos Aires: EUDEBA. 
Herrera, G. M., \& Requena, A. (2002). La planificación como proceso social. Gestión y Administración de Políticas Públicas, 25.

Herzer, H. (1990). Los desastres no son tan naturales como parecen. Medio Ambiente y Urbanización, 30, Buenos Aires: IIED-GEL.

Herzer, H., \& others (2002). Convivir con el riesgo o la gestión del riesgo. [Online] Available: www.cesam.org.ar/publicaciones.htm (January 28, 2019).

Laegreid, P., \& Verhoest, K. (2010). Governance of Public Organizations: proliferation, autonomy and performance. Hampshire: Palgrave MacMillan. https://doi.org/10.1057/9780230290600

Lavell, A. (2002a). Riesgo y Territorio: los niveles de intervención en la Gestión del Riesgo. Anuario Social y Político de América Latina y el Caribe, FLACSO-Nueva Sociedad.

Lavell, A. (2002b). Sobre la gestión del riesgo: apuntes hacia una definición. La Red. Lima: USAID.

Lavell, A. (2003). La Gestión Local del Riesgo. Nociones y Precisiones en torno al Concepto y la Práctica, CEPREDANEC - PNUD.

Mintzberg, H. (1998). La Estructuración de las Organizaciones. Barcelona: Ariel.

Mocellin, J., \& Rogge, J. (1996). Algunas dimensiones culturales, educativas y de salud mental en las características psicosociales de los desastres. Mansilla, Elizabeth (edit.), Desastres. Modelo para armar. Colección de piezas de un rompecabezas social, La Red, 176-191.

ONU-CEPAL. (2005). El impacto de los desastres naturales en el desarrollo: Documento metodológico básico para estudios nacionales de caso. [Online] Available: https://repositorio.cepal.org/bitstream/handle/11362/25766/LCmexL694_es.pdf?sequence=1 (January 28, 2019).

Peters, B. G. (1999). La política de la burocracia. México: Fondo de Cultura Económica.

Poggiese, H. (1993). Metodología FLACSO de Planificación-Gestión. Planificación participativa y gestión asociada. Buenos Aires: FLACSO.

Ramió, C. (1999). Teoría de la Organización y Administración Pública. Madrid: Tecnos / UPF.

Ramos, A. M. (2004). Metodología para la evaluación de una política de gestión de riesgos ante desastres naturales y antrópicos. Programa Iberoamericano de Ciencia y Tecnología para el Desarrollo - CYTED.

Rodríguez, V. D., \& others (coord.) (2008). Políticas Públicas y Desastres. México: Instituto Mora: Red Mexicana de Estudios Interdisciplinarios para la Prevención de Desastres.

Solanas, C., \& others (2011). Políticas públicas para la transferencia del riesgo climático. Observatorio de Políticas Públicas, Coordinación General del Cuerpo de Administradores 


\section{Macrothink}

Journal of Public Administration and Governance ISSN 2161-7104 2019, Vol. 9, No. 1

Gubernamentales. Jefatura de Gabinete de Ministros, República Argentina, CAT. OPP/CAG/2011-13. [Online] Available: www.cag.jgm.gov.ar (January 28, 2019).

Vargas, J. E. (2002). Políticas públicas para la reducción de la vulnerabilidad frente a los desastres naturales y socio - naturales. Serie Medio Ambiente, 50, División de Medio Ambiente y Asentamientos Humanos. Santiago de Chile: CEPAL.

\section{Copyright Disclaimer}

Copyright for this article is retained by the author(s), with first publication rights granted to the journal.

This is an open-access article distributed under the terms and conditions of the Creative Commons Attribution license (http://creativecommons.org/licenses/by/4.0/). 